\title{
Spinal Cord Injury Management through the Combination of Stem Cells and Implantable 3D Bioprinted Platforms
}

\author{
Atefeh Zarepour ${ }^{1}$, Sara Hooshmand ${ }^{2}$, Aylin Gökmen ${ }^{3}$, Ali Zarrabi ${ }^{1,2, *(\mathbb{D})}$ and Ebrahim Mostafavi ${ }^{4,5, *(D)}$ \\ 1 Department of Biomedical Engineering, Faculty of Engineering and Natural Sciences, Istinye University, \\ Istanbul 34396, Turkey; atefeh.zarepour@gmail.com \\ 2 Nanotechnology Research and Application Center (SUNUM), Sabanci University, Istanbul 34956, Turkey; \\ sara.houshmand@sabanciuniv.edu \\ 3 Molecular Biology and Genetics Department, Faculty of Engineering and Natural Sciences, \\ Bahcesehir University, Istanbul 34353, Turkey; aylingokmen00@gmail.com \\ 4 Stanford Cardiovascular Institute, Stanford University School of Medicine, Stanford, CA 94305, USA \\ 5 Department of Medicine, Stanford University School of Medicine, Stanford, CA 94305, USA \\ * Correspondence: alizarrabi@sabanciuniv.edu (A.Z.); ebimsv@stanford.edu or ebi.mostafavi@gmail.com (E.M.); \\ Tel.: +90-537-731-0182 (A.Z.); +1-617-5130314 (E.M.)
}

check for updates

Citation: Zarepour, A.; Hooshmand, S.; Gökmen, A.; Zarrabi, A.; Mostafavi, E. Spinal Cord Injury Management through the Combination of Stem Cells and Implantable 3D Bioprinted Platforms. Cells 2021, 10, 3189. https://doi.org/ 10.3390/cells10113189

Academic Editor: Alexander E. Kalyuzhny

Received: 1 October 2021

Accepted: 9 November 2021

Published: 16 November 2021

Publisher's Note: MDPI stays neutral with regard to jurisdictional claims in published maps and institutional affiliations.

Copyright: (c) 2021 by the authors. Licensee MDPI, Basel, Switzerland. This article is an open access article distributed under the terms and conditions of the Creative Commons Attribution (CC BY) license (https:/ / creativecommons.org/licenses/by/ $4.0 /)$.

\begin{abstract}
Spinal cord injury (SCI) has a major impact on affected patients due to its pathological consequences and absence of capacity for self-repair. Currently available therapies are unable to restore lost neural functions. Thus, there is a pressing need to develop novel treatments that will promote functional repair after SCI. Several experimental approaches have been explored to tackle SCI, including the combination of stem cells and 3D bioprinting. Implanted multipotent stem cells with self-renewing capacity and the ability to differentiate to a diversity of cell types are promising candidates for replacing dead cells in injured sites and restoring disrupted neural circuits. However, implanted stem cells need protection from the inflammatory agents in the injured area and support to guide them to appropriate differentiation. Not only are 3D bioprinted scaffolds able to protect stem cells, but they can also promote their differentiation and functional integration at the site of injury. In this review, we showcase some recent advances in the use of stem cells for the treatment of SCI, different types of 3D bioprinting methods, and the combined application of stem cells and 3D bioprinting technique for effective repair of SCI.
\end{abstract}

Keywords: spinal cord injury; stem cells; 3D bioprinting; tissue regeneration; neural tissue engineering

\section{Introduction}

Spinal cord injury (SCI) results in irreversible loss of sensory, motor, and autonomic functions [1]. Close to 500,000 individuals suffer from SCI every year (https:/ / sciprogress. com/understanding-spinal-cord-injuries / (accessed on 10 December 2020)). SCI affects not only patients' body function but also their socioeconomic conditions, and the disorder is often associated with considerable individual suffering and societal costs [2]. Current therapeutic options, which aim to minimize the extent of secondary damage and support recovery of function through rehabilitative measures $[3,4]$, are inadequate. Therefore, it is critical to develop an effective treatment for SCI.

Researchers have attempted to identify new treatments, such as drug administration, surgical decompression, hypothermia, and stem cells therapies, which could promote nerve cell regeneration, repair damaged parts, reduce the metabolic rate, and suppress acute inflammatory processes (to protect central nerve tissue from continued injury following traumatic damage) [5,6]. Recently, new therapeutic methods, such as cell/gene therapy, motor exercises, electrical stimulation, electrochemical neuromodulation therapy, and stem cell-based therapies, have been used, alone or in a combinatory approach, to achieve successful SCI therapy [7]. 
Stem cell-based therapies include applications with high potential, particularly in the SCI field, because of their self-renewable properties. Transplantation of stem cells is considered a promising strategy for the regeneration of dead cells or lost tissue caused by SCI, especially when combined with particular three-dimensional (3D) printed materials/scaffolds. Three-dimensional printing is a type of additive manufacturing (AM) developed by Charles Hull in 1986 based on the idea of "utilizing layers of materials on top of each other for printing a subject". Nowadays, 3D printing technology is applied in different fields and is especially used for biomedical applications. This has led to the emergence of a new type of 3D printing technology, known as 3D bioprinting, which is used for the creation of a cell pattern that could preserve the viability and functionality of cells $[8,9]$.

The combinatory approach of using 3D printed scaffolds and stem cells could be more effective in improving motor function in SCI than using a single therapeutic method [10]. Additionally, this combined therapy could enhance cell proliferation and neural differentiation in vitro while reducing inflammation and the formation of a cavity in vivo. This method shows an anti-inflammatory effect via suppressing the activated microglia or macrophages in the injury site [11]. That is, implantable polymeric scaffolds could be implanted to fill the gap created by SCI in the injury site and rejuvenate the axons in the restorative environment [12]. In SCI repair, biomaterial scaffolds play a crucial role in generating a microenvironment favorable for regeneration [13]; for instance, in addition to playing the role of a supporting platform, these biomaterial scaffolds could be employed as carriers for seeded cells to repair the microenvironment at the SCI site and, finally, to bridge the deficiency in SCI [14]. They could be used in a 3D porous structure to provide a suitable surface for cell growth and proliferation, as well as supporting the flow of nutrients, oxygen, and discharge of metabolites [15]. Moreover, different types of biological components could be applied in the structure of these scaffolds, thereby stimulating stem cell-scaffold interactions and promoting their therapeutic performance [16].

The main focus of this overview is to introduce the combined therapy of stem cells and different types of 3D printed scaffolds for SCI therapy. In this review, we discuss the utilization of different types of stem cells used for SCI, their mechanism of function, and new types of 3D bioprinted scaffolds used as platforms for stem cells in SCI therapy. A combinational approach using implantable platforms and stem cell therapy could provide novel and promising strategies for future studies and show potential for safe applications in further clinical trials.

\section{Stem Cell Therapy}

As a considerable challenge, SCI therapy has always been of great concern among clinical scientists due to its consequent irreparable tissue damage and constant sensorimotor impairment [17]. Stem cells are the only raw cells that could provide a repair system in the body through their natural ability to produce any type of specialized cells. These are cell lines with self-renewing capability, which makes them suitable for the treatment of SCI $[18,19]$. However, the wide application of stem cells in this field is restricted by their limited sources and immune rejection, as well as the ethical issues related to the transplantation of some types of stem cells [20]. Thus, to encourage further advances in the transplantation of stem cells to manage SCI, it is critical to use effective stem cell lines to prevent ethical issues and immune rejection [21]. Microenvironmental changes that occur in the injury site of the spinal cord could subsequently stop axonal regeneration. Stem cells could provide axonal trophic support to these microenvironments and consequently enhance vascularization, modify the inflammatory responses, and prevent cystic changes. To design such beneficial microenvironments for spinal cord restoration, stem cell therapy has been combined with other therapeutic methods, such as gene therapy, in which therapeutic effects of specific genes are transferred to the site of injury. These stem cells can replace injured neural cells and upregulate specific neurotrophic factors to reconstruct the spinal cord neural circuit [22]. 
Different stem cells could also be combined and transplanted to perform more effectively than a single cell in repairing SCI. This combination of different cell types enables unique neurotrophic factors in the injured area to stimulate axonal regeneration. Despite considerable effort in the field, further investigations should be performed to obtain optimal combination parameters and accomplish the greatest functional recovery from SCI [23].

\subsection{Therapeutic Mechanisms of Stem Cells}

Stem cells can be used for spinal cord therapy, as they tissue repair, neurotrophy, angiogenesis regeneration, and promotion (reconstruction of neurovascular units) [24]. Transplanted stem cells show anti-apoptotic effects by disturbing the balance between anti-apoptotic and pro-apoptotic factors and, thus, improving the survival of the tissue and enhancing neurological function resumption. They also exhibit anti-inflammatory effects by reducing the number of neutrophils and the expression of inflammatory proteins that upgrade the neurological function [25].

In some cases, the efficiency of spinal cord treatment is depended on the type of transplanted cells. For example, neuronal stem cells accelerate the process of SCI treatment by direct release of neurotrophic factors, such as the glial fibrillary acidic protein (GFAP), B-cell lymphoma-2 (Bcl-2), neurotrophin-3 (NT-3), and brain-derived neurotrophic factor (BDNF) [26].

Several therapeutic approaches have been proposed for stem cell-based treatments of SCI [27]. Stem cell-based approaches could regenerate the neuronal circuit by replacing the spinal cord's damaged neurons via the creation of new links with the host neurons in the spinal cord. Moreover, the formation of synapses and regeneration of axons could be promoted after stem cell transplantation via the interactions between stem cells and the surrounding tissues. This could also modify the injury site microenvironment and accelerate the growth of the neural axon by generating some neurotrophic growth factors [28]. Transplanted stem cells could also enhance the myelin formation around neural axons, both newly grown and previous ones, by differentiating into gliocytes and oligodendrocytes. This would lead to an increase in functional recovery of patients with spinal cord injuries, which is substantial in the repair process [29].

Stem cells could also be applied in combination with other therapeutic mechanisms that improve their effectiveness. For example, utilizing gene-modified stem cells, which express high levels of neurotrophic factors and neuronal cell adhesion molecules, could be a promising method for SCI treatment. It is noteworthy that this is a new therapeutic method, and more investigations are needed in this field to clarify all aspects in patients [30]. Nanomaterials could also be used as carriers of different types of drugs, delivering them to their targeted site without side effects on other parts, thus increasing the bioavailability of their cargos at the injury site. Based on the types of materials used for the fabrication of these nanomaterials, they could also affect the motor axon regeneration or inhibit inflammatory effects, which could help stem cells in proliferation and differentiation and promote SCI treatment [31].

Among the most promising tools that could improve the effectiveness of stem cells for spinal cord therapy are implantable scaffolds, especially 3D printed ones that are used at the site of injury. These multi-purpose tools fabricated from natural or synthetic agents could act as a niche for the transplantation of stem cells. They are fabricated from biocompatible materials and could directly affect the injured area by improving axonal regeneration [32].

\subsection{Different Types of Stem Cells Used for SCI}

Various types of stem cells have been applied to restore spinal cord injuries, including embryonic stem cells, induced pluripotent stem cells (iPSCs), mesenchymal stem cells, and neural stem cells [33]. Some of the most prevalent of these cells are described in detail in the following sections. 


\subsubsection{Embryonic Stem Cells}

Pluripotent embryonic stem cells are one of the interesting classes of stem cells derived from early-stage embryos. They show an unlimited dividing ability in a homogeneous state and the capability to convert into multiplex somatic cell types [34].

The efficiency of the transplantation of human embryonic stem cells as a promising approach in the treatment of SCI has been assessed via several studies. In a recent preclinical study, human embryonic stem cell-derived neural crest cells were tested as therapeutic candidates in an SCI model of adult rats. Utilizing these cells led to the enhancement of the sprouting function and partial recovery of the forelimb motor after being transplanted into both chronic and acute cervical SCI rat models. They could also stimulate the remodeling of descending raphespinal projections by producing different biologically active trophic factors [35].

In a recent survey, human embryonic stem cell-derived neural stem cells (hESC-NS) were transplanted into an SCI rat model via utilizing a type of hyaluronic acid-based hydrogel to evaluate the effect of cells on the regeneration of tissue and recovery of movement. According to the results of this study, the presence of hydrogel led to not only the differentiation of stem cells into three different types of neuronal cells (astrocytes, neurons, and oligodendrocytes) but also to enhancement of the neuronal myelination at the injury site. Moreover, the animal movements were improved after seven weeks of injury by developing locomotor functions [36].

\subsubsection{Induced Pluripotent Stem Cells (iPSC)}

Due its various advantages, iPSCs technology has been applied as a promising alternative therapy for difficult-to-treat spinal cord injuries in escalating morbidity cases. iPSCs are artificial stem cells with proliferative and self-renewal abilities that are derived from somatic cells via their reprogramming through the expression of defined pluripotencyassociated factors. These cells can easily be differentiated into the precursor cells of all neural cell types at the SCI site and demonstrate remarkable potential in SCI therapeutic applications [37,38].

The combined use of iPSC-derived neural stem cells and long non-coding RNAgrowth arrest-specific transcript 5 (lncRNA-GAS5) could inhibit neuronal apoptosis and promote repair of the SCI. The results of a Western blot analysis indicated an increase in the expression level of $\mathrm{B}$ cell lymphoma/leukemia-2 along with a decrease in the amount of Bcl2 associated $\mathrm{X}$ protein, cytochrome $\mathrm{C}$, and cleaved caspase-3. Morphological observations confirmed that the transplantation of cells could improve renovation in mouse model of SCI, while the restorative effects of the transplantation were inhibited by the growth arrest-specific 5 (GAS5) silencing gene [39].

A critical point about utilizing iPSCs for SCI treatment is the regional identity of the neural progenitor cells (NPCs) derived from iPSCs. This factor was assessed in a study in which two types of NPCs (forebrain- and spinal cord-type NPCs) were fabricated from human iPSCs and transplanted into an SCI mouse model. The results of this study revealed that only mice treated with spinal cord-type NPCs showed an improvement in their motor recovery, and the other types of cells could not exhibit any significant effect on SCI treatment [40].

\subsubsection{Mesenchymal Stem Cells}

Mesenchymal stem cells are the best candidates for the treatment of SCI, and they have been widely applied in regenerative medicine due to their unique characteristics in injured tissues, such as high availability, multi-potency, immunomodulation, and self-regeneration, as well as being easily isolated and cultured [41]. However, this modern medication has shown minimal progress in developing injured nerve functions in SCI patients, mainly due to the complicated pathophysiological variations that appear after the occurrence of injuries [22]. 
Mesenchymal stem cells could repair SCI through the macrophage polarization mechanism. The functions of immune cells at various SCI sites may differ over time and cause post-inflammatory reactions that could lead to secondary injuries at the injury site. The key mediators of inflammatory responses after SCI are two different subtypes of macrophages, classically activated macrophages (M1 macrophages) and the alternatively activated macrophages (M2 macrophages), or pro-inflammatory and anti-inflammatory macrophages, respectively, which have immunoregulatory potentials. That is, the activation of M1 macrophages is accompanied by elevated amounts of oxidative metabolites (such as nitric oxide and superoxide) and pro-inflammatory cytokines that could damage the healthy tissues around the injured region, while M2 macrophages could promote tissue regeneration and provide resistance against body inflammation. The therapeutic effect of mesenchymal stem cells is due to their particular immune microenvironments, which impact macrophage polarization and subsequently control the effects of secondary injury (after SCI) by establishing higher recovery of nerve functions (Figure 1) [42].

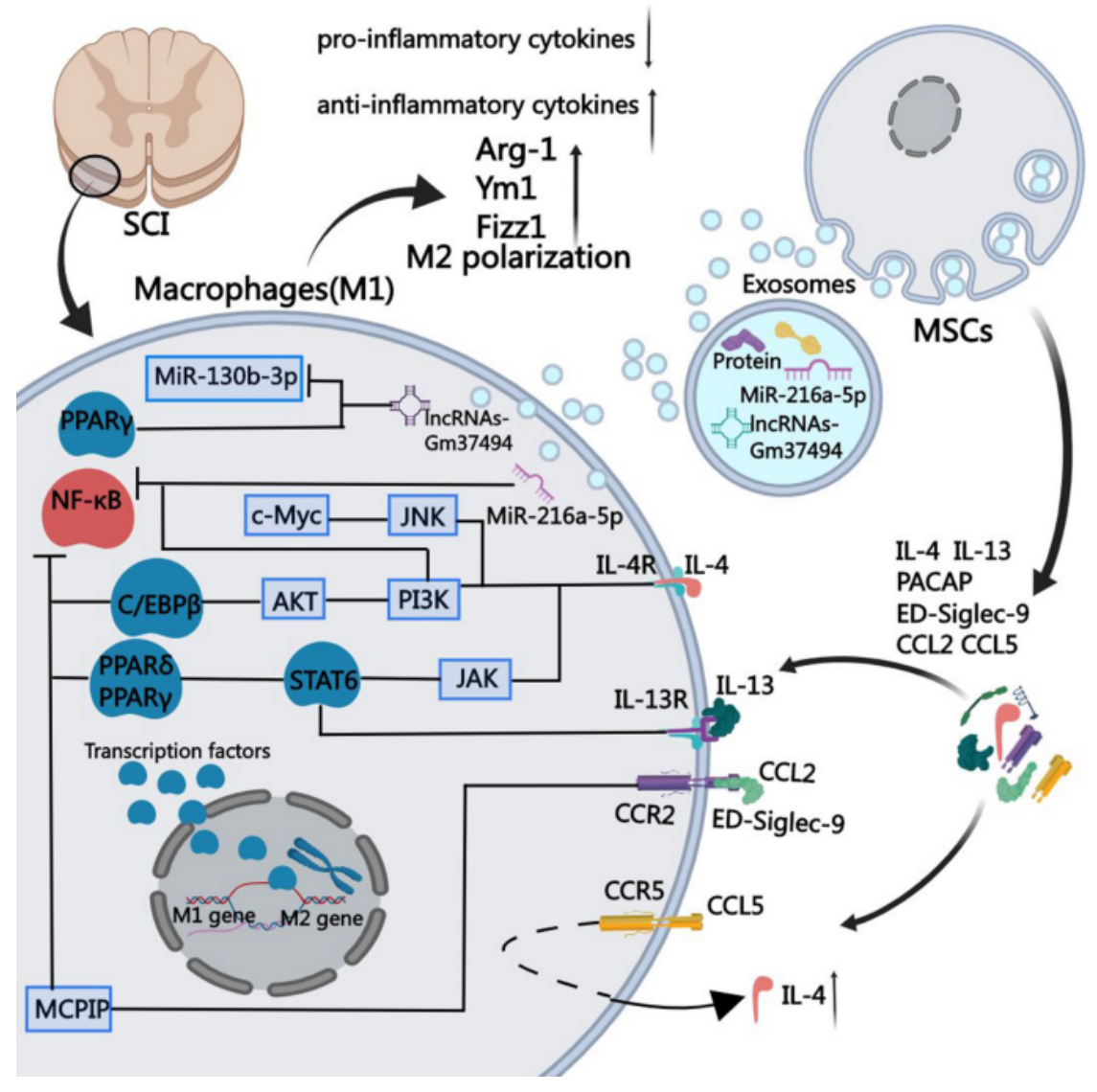

Figure 1. Mechanism of regulation of macrophage polarization by mesenchymal stem cells by stimulating them at the site of SCI, which could produce soluble proteins of chemokine (C-C motif) ligand 2 (CCL2), chemokine (C-C motif) ligand 5 (CCL5), interleukin 4 (IL-4), interleukin 13 (IL-13), sialic acid-binding Ig-like lectin 9 (ED-Siglec-9), and pituitary adenylate cyclase-activating peptide (PACAP) [42].

The implantation effects of mesenchymal stem cell progenitors on animals and clinical models of SCI have also been studied. These cells could be obtained from different tissues, such as adipose tissue, bone marrow, or Wharton jelly, easily expanded in vitro due to their multi-lineage differentiation potential and adjusted dendritic cell activity owing to their immunomodulatory and paracrine potential. Since they are hypoimmunogenic, they could result in better regeneration by transferring to lesion sites to protect perineuronal nets and promote neural plasticity [43]. 


\subsubsection{Neural Stem Cells (NSCs)}

Neural stem cells are another type of stem cells that are being progressively applied in SCI treatment. They are a multipotent subtype of progenitor cells in the nervous system and can be derived from three main sources: primary central nervous system (CNS) tissue, pluripotent stem cells, and somatic cells. Similar to other types of stem cells, they have a self-renewing ability and can easily differentiate into different types of neuronal cells, such as neurons, oligodendrocytes, and astrocytes [44]. After spinal cord injury, transplanted NSCs could play a key role in nerve regeneration and nutrition [26]. The combined use of NSCs and fibroblast growth factor (FGF) has revealed promising effects in the therapy of SCI; however, employing these strategies to repair SCI is still a challenging issue due to hostile hypoxia conditions. Indeed, hostile hypoxia conditions do not allow stem cells to survive and self-regulate, and it is necessary to provide a condition that could overcome these challenges and lead to regulation of the expression of FGF and an improvement in cell survival. In a recent study, a prototype adeno-associated virus (AAV2) was transduced into NSCs that can regulate the expression of the FGF gene under the hypoxia response element (HRE) condition (AAV2-5HRE-bFGF-NSCs). According to a mechanistic study, this therapy could increase the expression of basic FGF and enhance total functional recovery compared to the control group (AAV2-5HRE-NSCs) by increasing the expression of specific neuronal proteins and reducing the expression of the glial fibrillary acidic protein and autophagy-associated proteins (Figure 2). Overall, AAV2-5HRE-bFGF-NSCs treatment could upgrade the recovery of SCI in rats by enhancing successful nerve regeneration as well as inhibiting cell autophagy and glial scar formation [45].

Genetically modified human NSCs (hNSCs) were applied to detect the stimulating effect of these cells on the functional recovery of the injured spinal cord. The results of MRI tests proved the migration of transplanted cells toward the injury site of the spinal cord that could functionally connect to host neurons and substantially enhance locomotor functions while expressing neural lineage markers. These results imply that the transplantation of these cells could regulate inflammatory cells and glia activation and improve the hyperalgesia that occurred after SCI [45].

Moreover, the combination transplantation of NSCs and human olfactory ensheathing mucosa cells has shown effectiveness in preclinical trials to treat post-traumatic cysts of spinal cord injuries. This co-transplantation improved the hind limbs' motor activity and led to a cyst size reduction of $4-12 \%$ in rats [46]. Some of the advantages and limitations of different types of stem cells are summarized in Table 1.

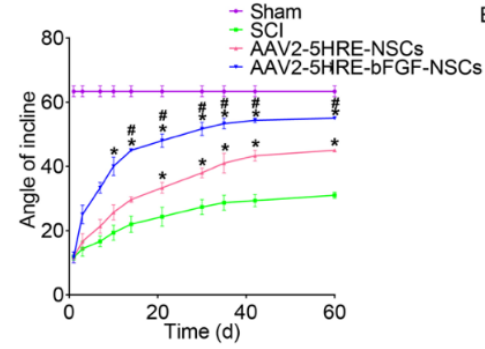

C

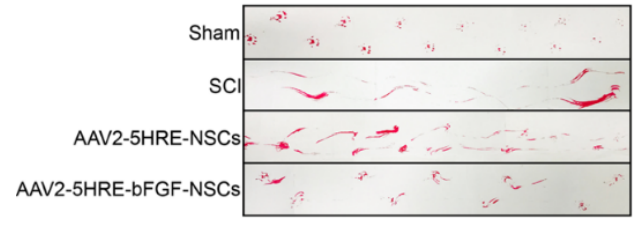

B
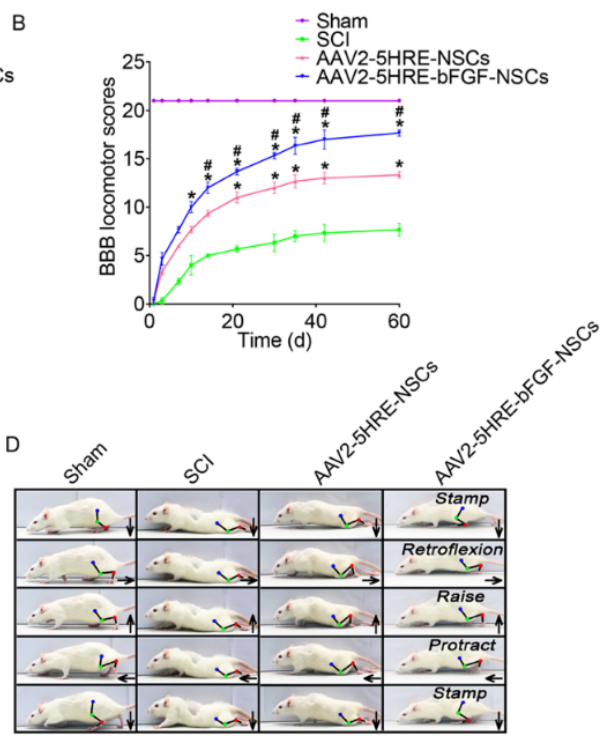

Figure 2. Cont. 
E

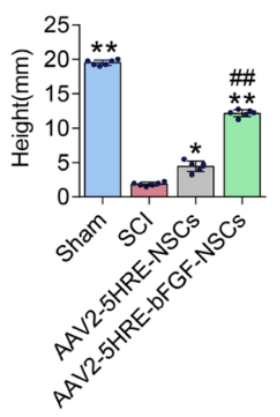

F

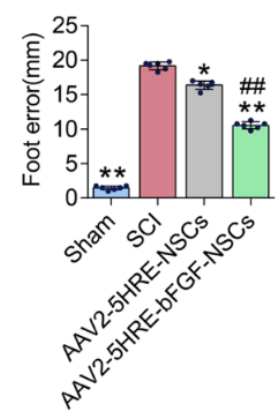

G

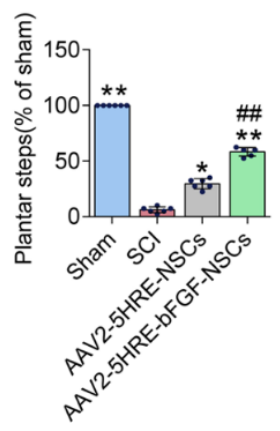

Figure 2. (A) The inclined plane test scores of sham, SCI group, adeno-associated virus 2-5HRE- neural stem cell (AAV2-5HRE-NSC) group, and AAV2-5HRE-basic FGF-NSC group. (B) The Basso-BeattieBresnahan (BBB) scales of sham, SCI group, AAV2-5HRE-NSC group, and AAV2-5HRE-bFGF-NSC group. Data are reported as the mean values \pm SEM $(n=3)$. (C) Footprint examinations of the four studied groups. (D) Video sequences of a rat walking 2 months after SCI. Arrows indicate foot movement. Scale bar $=20 \mathrm{~mm}$. (E) Height of the trunk from the ground reported as weight support, (F) foot error, and $(G)$ plantar step. Data are reported as the mean values $\pm \operatorname{SEM}(n=6)$. \# attributed to the $p<0.05$, AAV2-5HRE-NSCs group verse SCI group, ${ }^{*}$ is attributed to the $p<0.05$, AAV2-5HREbFGF-NSCs verse AAV2-5HRE-NSC group, ${ }^{* *}$ is represented the $p<0.01$, versus the SCI group or sham group, and finally \#\# is represented the $p<0.01$, versus the AAV2-5HRE-NSCs group [45].

Table 1. The advantages and limitations of different types of stem cells in SCI therapy.

\begin{tabular}{|c|c|c|c|}
\hline Type of Stem Cells & Benefits & Restrictions & Ref. \\
\hline Embryonic stem cells & 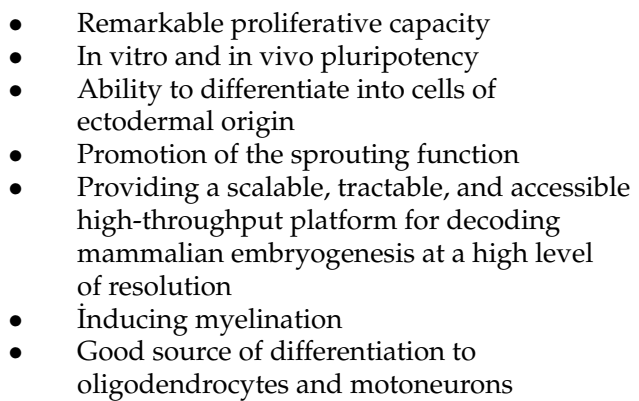 & $\begin{array}{l}\text { - } \quad \text { Ethical controversies } \\
\text { Partial recovery of forelimb motor after being } \\
\text { transplanted into both chronic and acute } \\
\text { cervical spinal cord injury rat models } \\
\text { - } \quad \text { Probability of tumor formation }\end{array}$ & {$[35,36,47]$} \\
\hline
\end{tabular}

Induced pluripotent stem cells
- Prevention of ethical considerations and immunological rejection via use of patient-specific iPSCs

- Inhibition of neuronal apoptosis

- Promotion of myelin production by oligodendrocytes

- Modulation of immunopathological events
- Inhibition of restorative effects of the transplantation via GAS5 silencing gene

- Several risks, such as uncontrolled expression of integrated transgenes, insertional mutagenesis, tumor formation, and silencing or downregulation of transgenes

- Aberrant reprogramming

- $\quad$ Presence of transgenes
- $\quad$ Easy isolation (from different sources)

- Good preservation

- Reduction in ethical concern

- $\quad$ Reduced risk of tumors development

- High regenerative potential after freezing

- Rapid proliferation

- Obtaining high multilineage differentiation

- Low immunoreactivity

- "Homing" capability

- Control of the effects of secondary injury (after SCI)

- Establishment of higher recovery of nerve functions
- Low survival rate

- Lack of enough evidence on differentiating MScs to neuronal cells

- Differentiation of transplanted cells into other types of cells, such as osteoblasts, which limits their therapeutic effects

- Unsatisfactory translation from small animal experimental models (mice and rats) into human clinical practice

- Usually have paracrine activity instead of cellular replacement mechanisms 
Table 1. Cont.

\begin{tabular}{|c|c|c|c|}
\hline Type of Stem Cells & Benefits & Restrictions & Ref. \\
\hline Neural stem cells & $\begin{array}{l}\text { - } \quad \text { Promotion of remyelination of axons } \\
\text { High self-renewal capability in } \\
\text { in vitro culturing } \\
\text { - More preferable than hESCs in } \\
\text { clinical applications } \\
\text { - Less potential of tumor formation }\end{array}$ & $\begin{array}{l}\text { - } \quad \text { Glial scar formation } \\
\text { Limited differentiating potential in clinical } \\
\text { trial after several passages } \\
\text { Their cell survival and integration highly } \\
\text { dependent on their source of transplantation } \\
\text { and isolation methods } \\
\text { - } \quad \text { Need purification } \\
\text { - } \quad \text { Inoderate cell survival } \\
\text { - } \quad \text { Lack of neurotrophic factors }\end{array}$ & [49] \\
\hline
\end{tabular}

Due to the critical role of biomaterial scaffolds in forming a beneficial regeneration microenvironment for repairing injured spinal cord tissues, they have been used as supporting and carrier platforms for stem cells. The combined use of stem cells and scaffolds could facilitate the reconstruction of the microenvironment at the injury site [50]. Moreover, immobilizing cells into scaffolds could control the diffusion rate after implantation [15]. In the following section, recent developments in the preparation of 3D printed scaffolds and their combined use with different types of stem cells for SCI treatments are reviewed.

\section{Application of 3D Bioprinting in Spinal Cord Injury Repair}

As discussed in the previous section, the main aspects of SCI cure are the regeneration of functional neurons at the injured area with an adequate connection to the neighborhood tissues and, thus, the restoration of the nerve conduction function [51]. It was initially suggested that NSCs should be directly implanted in the injured area, as this may lead to the production of tissue with partial neural circuits and functions; however, it may also show limitations, such as uncontrolled differentiation of NSCs and a high number of dead implanted cells [52]. In this case, applying tissue engineering methods could help generate replaceable neural tissue with the required functionality. Generally, the physical support for regenerated tissue is provided by 3D scaffolds, which should have some specific properties if they are to be used inside the body. These properties include but are not limited to the following [53]:

- They should be made of biocompatible materials to improve the attachment and proliferation of cells and to guarantee the lack of immune and cytotoxic reactions. Moreover, these materials should also be biodegradable to ensure the substitution of the scaffold with the regenerated tissue in a specified time.

- They should have enough mechanical strength to ensure a low-stress level in the lesion region and to prevent collapse in this area throughout regular motion.

- They should contain an interconnected pore size at the microscale level to mimic the extracellular matrix of the natural tissue and to facilitate waste and nutrient exchange.

- Finally, they should have electrical conductivity to assist in neurite growth and neuro-regeneration.

The conventional methods used for the production of scaffolds are gas foaming, melt molding, electrospinning, sacrificial templating, and phase separation [54,55]. Gas foaming a low-cost method used to produce a porous 3D structure in which polymers are used in combination with a gas foaming agent that acts as a plasticizer and eliminates the glass transition and/or melting temperature of the polymers. It is a clean and flexible method for the production of porous structure at the micron scale; however, it also has some limitations restricting its wide application. For instance, it cannot be used for crystalline polymers since it cannot decrease the glass transition temperature of these polymers [56].

In the melt molding technique, a mixture of porogen and polymeric powder is prepared inside the mold and heated under pressure above the polymer glass transition temperature. This heating process leads to the production of a scaffold by making connec- 
tions between polymer and porogens. Then, the porogens are extracted by immersing the mold in water, and, subsequently, the porous structure is fabricated. Although utilizing this method could produce a porous structure with a controllable shape, the high probability of contamination in the pores could restrict the application of this method [57].

Electrospinning is another interesting method, and it has been widely used in recent research. This technique is based on applying high-voltage electricity to a polymeric solution to fabricate fibrous scaffolds. A suitable scaffold could be prepared by controlling different parameters of the spinning process, thereby providing an appropriate platform for tissue engineering applications. That is, it could present a nanoscale/microscale porous structure that could mimic the natural extracellular matrix of tissues. Moreover, it could contain bioactive factors and functional drugs needed to regenerate the function of a tissue. For instance, this technique could be used in nerve tissue regeneration via the formation of nerve guidance conduits (NGCs), which are suitable for the self-repairing process. The main limitation of this method is the utilization of solvents that could be toxic to live cells. Moreover, the dense fibrous structure of the electrospun scaffold could limit their applications in 3D tissue engineering due to poor cell infiltration $[1,58]$.

As is well known, most of the techniques mentioned above encounter limitations that could diminish their usage in tissue engineering applications. In recent years, a new powerful technique known as additive manufacturing (AM) has been introduced by scientists for the fabrication of scaffolds and it is widely used in different fields, from aerospace, automobile manufacture, and construction to different areas of medical science, especially tissue engineering. It is based on the fabrication of a 3D structure during a layerby-layer fabrication process with the help of computer-aided design (CAD) or computer tomography (CT) scan images. This technique was introduced in 1986 by Charles W. Hull, who used stereolithography (SLA) to form 3D systems based on using a preprogrammed computer-controlled moving laser beam. Using AM in tissue engineering could overcome most of the limitations of other techniques via control of the porosity, chemistry, and complexity of the fabricated scaffold [59].

Different types of natural and synthetic polymers, ceramics, and metals could be used to fabricate 3D printed scaffolds. In addition to SLA, several other types of printing methods have been introduced, such as multi-jet modeling (MJM), selective laser sintering (SLS), digital light processing (DLP), laminated object manufacturing (LOM), fused deposition modeling (FDM), and micro-extrusion. SLA and DLP are based on utilizing liquid photopolymer resins and ultraviolet (UV) lasers. MJM is a type of inkjet bioprinting process that is based on the use of print head technologies for layer-by-layer deposition of photo-curable plastic resins. FDM is a simple method that uses thermoplastic filaments for printing; SLS uses a high-power laser to fuse small particles to fabricate 3D structures. LOM is based on the use of sheet materials in the form of stacking layers, and, finally, micro-extrusion is based on utilizing micro-size nozzles for the synthesis of miniaturized scaffolds with enhanced accuracy [60,61].

Among the various types of AM methods, inject printing, SLA, fused deposition modeling (FDM), and micro-extrusion are the most common and extensively used methods for the production of 3D printed scaffolds [62]. The advantages and disadvantages of these methods are presented in Table 2.

As mentioned in the above section, one of the most important areas where the 3D printing technique could be applied is the fabrication of tissue constructs for regenerative medicine. This type of 3D printing is known as 3D bioprinting, and it is conceptually similar to 3D printing. Generally, in 3D printing, materials such as polymeric resins, metal, plastic, and rubber are used to print the desired structure, while in 3D bioprinting, biological materials or bioinks are employed. Bioinks are typically laden with living human or mammalian cells and usually have growth factors or biomaterial that could increase the bioactivity of scaffolds. Among the mentioned methods, microextrusion, laser-assisted bioprinting, and inkjet bioprinting are suitable for bioprinting applications (Figure 3). In the extrusion method (or robotic method), biopolymers or cell-laden hydrogels are 
dispensed through a nozzle using mechanical systems or air pressure. In laser-assisted bioprinting, laser pulses are applied to create high pressure on the donor slide, directing the cell-laden hydrogel droplets to the collector part. In inkjet printing, cell-laden hydrogels or biopolymer droplets are ejected via a nozzle by utilizing a piezoelectric actuator or thermal energy [64].

Table 2. Pros and cons of the AM methods used for tissue engineering applications [63].

\begin{tabular}{|c|c|c|}
\hline $\begin{array}{l}\text { Different Types of } \\
\text { AM Methods }\end{array}$ & Advantages & Disadvantages \\
\hline Inkjet bioprinting & $\begin{array}{l}\text { - } \quad \text { Cost-effective technique } \\
\text { - } \quad \text { High-speed printing and good resolution } \\
\text { Cell printing ability }\end{array}$ & $\begin{array}{l}\text { Produces structures with low mechanical } \\
\text { properties } \\
\text { High cell concentrations ( }>5 \text { million cells } / \mathrm{mL} \text { ) } \\
\text { must be seeded } \\
\text { - } \begin{array}{l}\text { Possible harm to cells due to heating ink } \\
\text { during the printing process }\end{array}\end{array}$ \\
\hline $\begin{array}{l}\text { Fused deposition } \\
\text { modeling (FDM) }\end{array}$ & $\begin{array}{ll}\text { - } & \text { Simple process } \\
\text { - } & \text { Low cost } \\
\text { - } & \text { High-speed printing }\end{array}$ & $\begin{array}{l}\text { - Due to the high temperature at the nozzle, it is } \\
\text { not suitable for cell printing } \\
\text { - Poor surface property }\end{array}$ \\
\hline $\begin{array}{l}\text { Stereolithography } \\
\text { (SLA) }\end{array}$ & $\begin{array}{l}\text { - } \quad \text { Very high printing resolution } \\
\text { - High surface quality }\end{array}$ & $\begin{array}{l}\text { - } \\
\text { - } \quad \text { Restriction of types of materials for 3D printing } \\
\text { is possible }\end{array}$ \\
\hline Micro-extrusion & $\begin{array}{l}\text { - } \quad \text { Cost-effective method } \\
\text { - } \quad \text { High viscosity ink can be printed } \\
\text { - } \quad \text { Ink with high cell density can be used } \\
\text { - } \quad \text { High-speed printing }\end{array}$ & - Shear stress at the nozzle may cause harm to cells \\
\hline
\end{tabular}

A

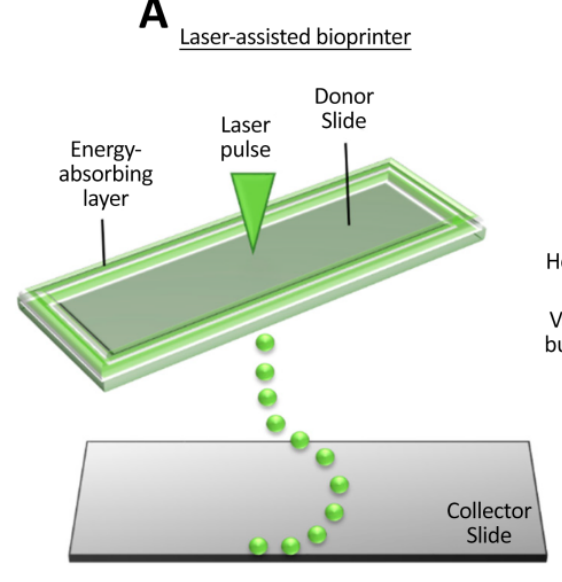

B

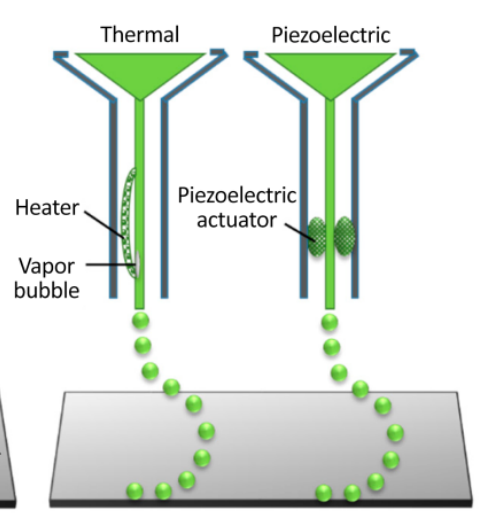

C Extrusion bioprinter

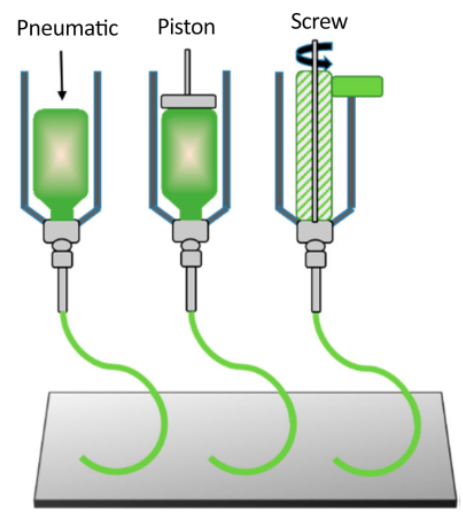

Figure 3. The most prevalent 3D bioprinting methods, which are used for tissue engineering applications. (A) Laser-assisted bioprinting, (B) Inkjet bioprinting, and (C) Microextrusion [64].

Before the printing process, one must consider the important features of the bioink (i.e., viscosity, crosslinking, and gelation properties) that can affect the quality and morphology of the scaffold and its ability in adsorbing cells, which, in turn, can promote their proliferation. Moreover, the most probable limitations of using bioprinting techniques for regenerative medicine applications are legal, ethical, and social concerns, and, as such, these must be addressed before their utilization in clinical applications [65]. 
SCI contusions lead to an irregularly shaped cavity in the injury site, which is surrounded by preserved white matter. The ideal way of reducing further damage to the injury site is the insertion of biomaterials in the cavity to improve the treatment process. Bioprinted scaffolds are among the most interesting candidates that could be used as filler in the injury site. They can mimic the structure of the extracellular matrix and promote cell proliferation and tissue regeneration, as well as being able to improve the regrowth of axons in the lesion and restoring neural circuitry [66].

One of the most interesting features of 3D printed scaffolds, which distinguishes them from other type of scaffolds for SCI applications, is the addition of cells in their structure during the synthesis process. This allows for a dense and uniformly distributed structure to be prepared, as well as providing a good microenvironment for cell-cell and cell-scaffold interactions in the lesion region, thereby facilitating neuron regeneration and reinstate neural circuitry [66]. The following section summarizes some of the recent studies in which 3D bioprinted scaffolds were used in combination with different types of stem cells for SCI therapy applications.

\section{Combination of 3D Bioprinted Scaffolds and Stem Cells for SCI Therapy}

To date, various studies with the aim of identifying a suitable method for the treatment of spinal cord injuries have been conducted. Among such methods, the simultaneous application of 3D bioprinting and stem cells has become the subject of considerable interest. Several types of hydrogels and biomaterials have been used for the fabrication of scaffolds for SCI research [67]. The constructed scaffold should have features that can provide specific physicochemical and biological conditions for stem cell attachment and promote their differentiation into neural phenotypes. In addition, bioprinting could result in acceptable models with favorable biochemical and mechanical properties and tunable microstructures for the evaluation of SCI. By controlling different synthetic parameters, such as shear stress, temperature, and pressure, scientists can produce scaffolds with a high number of live cells. Bioink is another important factor, and it should be considered during the fabrication of scaffolds with stem cells, as it could directly affect the viability of the cells and their differentiation ability $[68,69]$.

By considering all of the above-mentioned features, Vega and coworkers fabricated a 3D bioprinted scaffold utilizing fibrin-based bioink and human-induced pluripotent stem cells (hiPSCs) to study SCI. They provided structures with more than $81 \%$ viable cells, in which the stem cells could be differentiated into motor neurons while expressing the neuronal marker 15 days after culturing [70].

An aligned collagen scaffold was also used with neural stem/progenitor cells (NSPCs) for SCI therapy. It was revealed that NSPCs can fabricate a conducive microenvironment for neuronal regeneration and recovery of functions. The fabricated scaffold could provide support for cellular growth and differentiation and a guide for axonal extension. Moreover, it could promote neuro-regeneration and remyelination. The effect of stem cell source on SCI therapy performance has also been examined via the use of two types of NSPCs (brain-derived NSPCs (hbNSPCs) and spinal cord-derived NSPCs (hscNSPCs). The results revealed that spinal-derived stem cells acted more effectively than brain-derived NSPCs in promoting cell survival and neuronal differentiation and reducing the formation of glial scar and inflammatory agents while also improving the recovery of the locomotor functions in tested animal models (Figure 4) [2].

The combined use of iPSC-derived neural stem cells (iPSC-NSCs) and activated Schwann cells (ASCs) loaded on polycaprolactone (PCL) scaffolds was examined on an SCI animal model. The results of this study confirmed the cells' effectiveness in reducing lesion cavity volume and improving the recovery of locomotor. Utilizing ASCs could improve neuronal survival and induce axon myelination. The co-culturing of ASCs by stem cells could accelerate neuron differentiation and enhance nerve ending recovery. In addition, the PCL scaffold has excellent properties, such as mechanical stability, biodegradability, 
biocompatibility, and high processability, which make it appropriate for cell transplantation [71].

A

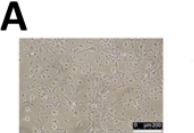

hbNSPCs
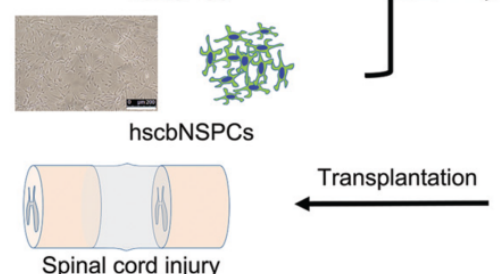
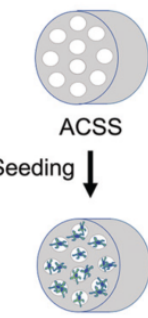

NSPC-ACSS

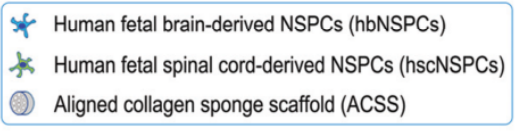

B
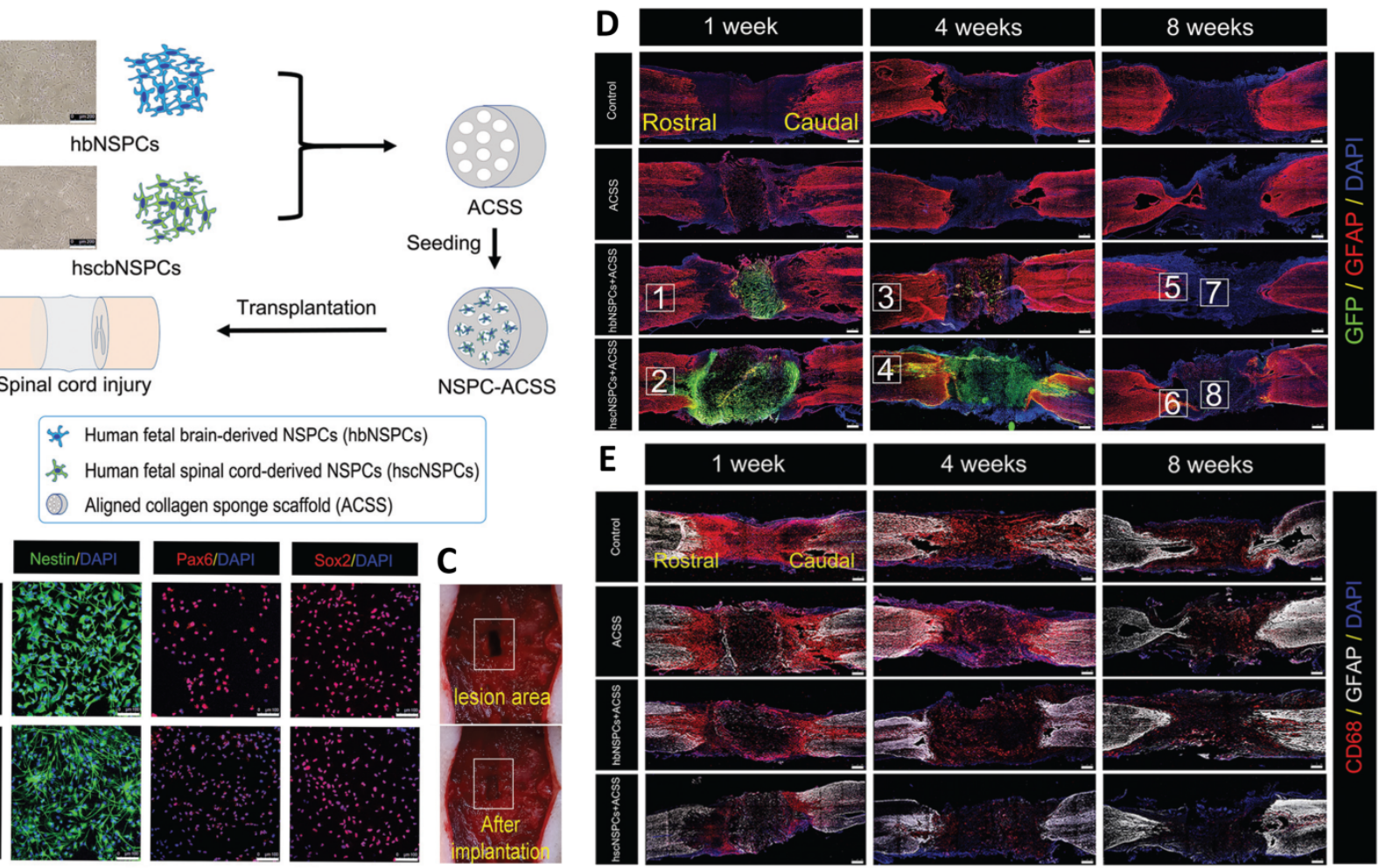

Figure 4. (A) Schematic of transplantation of hbNSPCs and hscNSPCs into the aligned collagen scaffold, Scale bars: 200 $\mu \mathrm{m}$. (B) Immunofluorescence images of hbNSPCs and hscNSPCs, Scale bars: $100 \mu \mathrm{m}$. (C) Transplantation of the scaffold in an animal model. (D) Survival images of transplanted cells (hbNSPCs and hscNSPCs) after 1, 4, and 8 weeks. The images clearly show that hbNSPCs cells are not alive after 4 weeks (green dye) (the red dye responded to astrocytes), Scale bars: $250 \mu \mathrm{m}$. (E) Effect of two types of stem cells on suppression of inflammatory agents. hscNSPCs showed a better anti-inflammatory effect than that of hbNSPCs, Scale bars: $250 \mu \mathrm{m}$. Reprinted from [2] with permission from the Royal Society of Chemistry.

To increase the scaffolds' physicomechanical performances, it is possible to use composite hydrogels instead of simple ones, thereby benefiting from the advantages of different materials and thus meeting the mechanical and physiological requirements of the host tissues [72]. For instance, the composite of collagen/heparin sulfate scaffolds has been produced for SCI application with uniform pore distributions and improved mechanical and neurological properties. This composite could exhibit high biocompatibility in the presence of stem cells and also acted as a good carrier for basic fibroblast growth factor (bFGF) immobilization [73].

In a recent study, the combination of NSCs and a 3D bioprinted collagen/silk fibroin scaffold promoted nerve regeneration after SCI in rat models. The results of this study showed a significant effect of the combined use of both factors compared to that of sole factors. Indeed, the combined use of scaffold and stem cells could abundantly regenerate axons, reduce glial scarring, and elevate the amounts of neurological scores [74].

In another study, the extrusion method was used for the fabrication of a multi-material 3D bioprinting scaffold containing clusters of iPSC-derived spinal neural progenitor cells (sNPCs) and oligodendrocyte progenitor cells (OPCs) (Figure 5). The NPCs could differentiate, and axons were extended throughout the scaffold. The combination use of stem cells and OPCs improved the recovery of axonal connections across the injured areas [75]. 

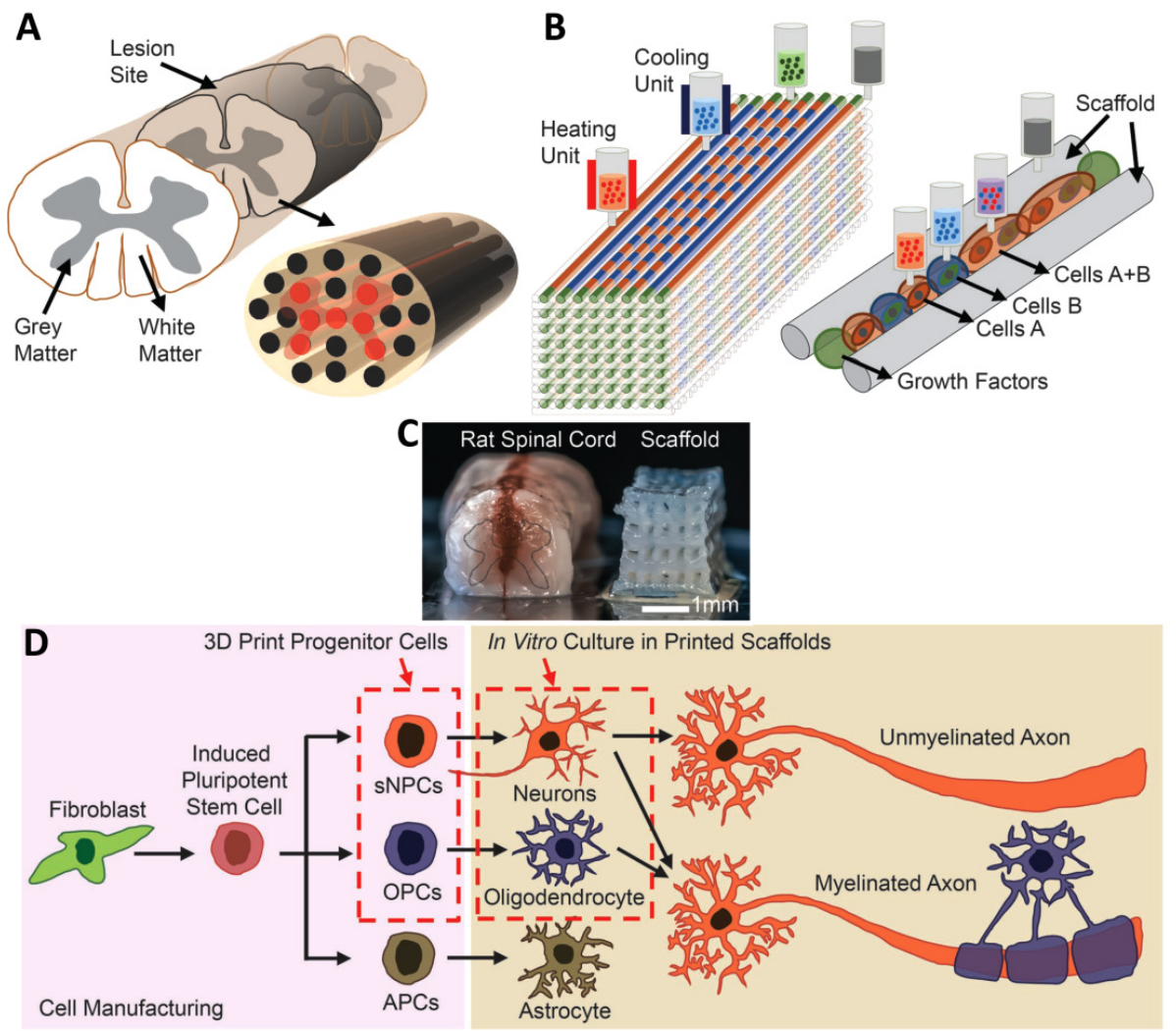

Figure 5. (A) Schematic of the spinal cord and 3D bioprinted scaffold. (B) Schematic of the extrusion bioprinting process. (C) Comparison of a real spinal cord and the fabricated scaffold. (D) Schematic of differentiation of iPSCs into three different types of neuronal cells. Reprinted from [75] with permission from Wiley Online Library.

Liu et al. [66] used microextrusion to fabricate 3D scaffolds for SCI repair (Figure 6). Their study used a cell-laden bioink consisting of chitosan, hyaluronic acid derivatives, Matrigel, and NSCs. This bioink showed fast gelation (within 20 s) and spontaneous covalent crosslinking capability, facilitating convenient one-step bioprinting of spinal cord-like constructs. These authors also investigated the performance of scaffolds using an in vivo rat model. Their results showed that the printed scaffolds have high cell viability, i.e., $95 \%$, and could improve neural tissue regeneration while decreasing glial scar deposition. In Table 3, a summary of some recent works in this area is presented.

A

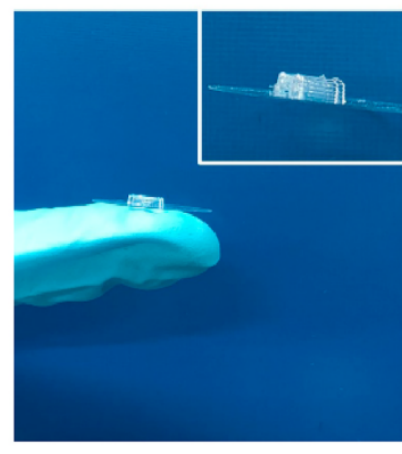

B

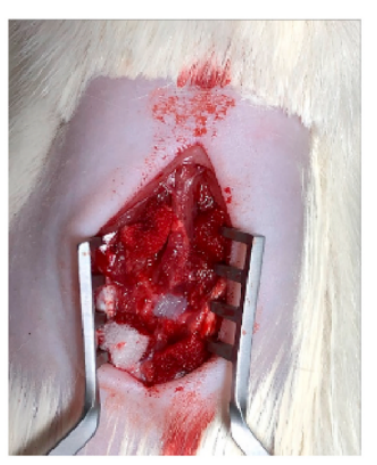

Figure 6. Cont.

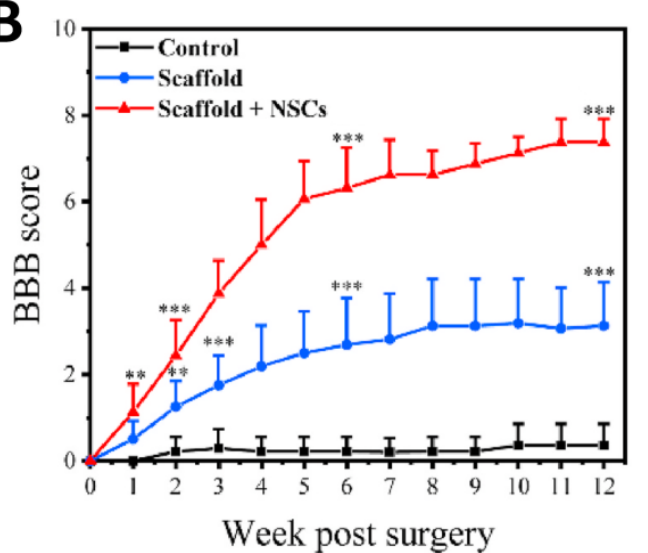

Week post surgery 

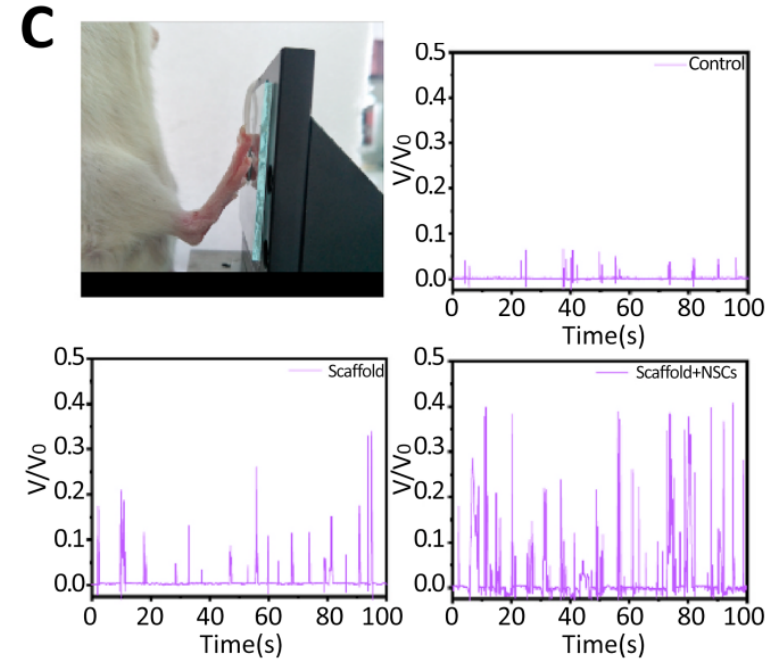

D

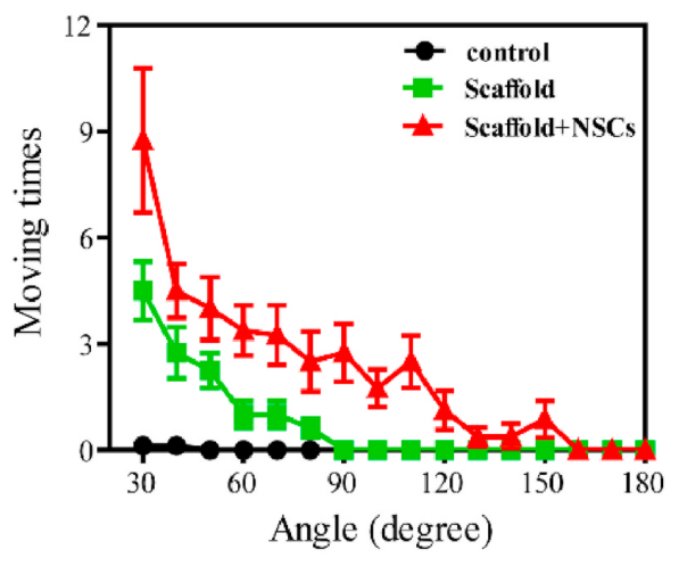

Figure 6. Functional recovery of SCI rats after three months of implantation. (A) Photographs of the scaffold with parallel linear arrays and implantation of the 3D bioprinted scaffold into the gap of the lesion area of SCI rats. (B) Basso-BeattieBresnahan (BBB) scores of rats in each group, ${ }^{* *} p<0.01,{ }^{* * *} p<0.001$. (C) Image of SCI rats kicking the pressure sensor. Record of hindlimbs of SCI rats kicking the pressure sensor, and their relative voltages corresponding the hindlimb movement of SCI rats in the control, scaffold, and scaffold + NSCs groups. (D) Ankle angle distribution of SCI rats in the control, scaffold, and scaffold + NSCs groups). Reprinted from [66] with permission from Elsevier.

Table 3. Some previous studies related to 3D bioprinting applications of neural tissue engineering.

\begin{tabular}{|c|c|c|c|c|}
\hline Print Method & Materials and Cell & Type of Study & Results & Ref. \\
\hline Microextrusion & Polyurethane-PCL-NSCs & In vitro & $\begin{array}{l}\text { High cell growth and differentiation } \\
\text { were observed on the scaffold. }\end{array}$ & [76] \\
\hline Microextrusion & $\begin{array}{l}\text { Composite hydrogel of alginate, } \\
\text { carboxymethyl chitosan, and agarose } \\
\text { laden with NSCs }\end{array}$ & In vitro & $\begin{array}{l}\text { Cell viability and differentiation } \\
\text { were observed. }\end{array}$ & [77] \\
\hline SLA & GelMa, graphene nanoplatelet-NSCs & In vitro & $\begin{array}{l}\text { Homogenous cell distribution } \\
\text { throughout all scaffolds was } \\
\text { observed, and neurites spread from } \\
\text { soma after } 14 \text { days of culture. }\end{array}$ & [78] \\
\hline SLA & $\begin{array}{c}\text { Composite hydrogel GelMa and } \\
\text { PEGDA-NSCs }\end{array}$ & In vitro & $\begin{array}{l}\text { Light stimulation increased NSC } \\
\text { neuronal differentiation and } \\
\text { inhibited the generation of glial cells. }\end{array}$ & [79] \\
\hline SLA & $\begin{array}{l}\text { Poly(3,4-ethylenedioxythiophene) } \\
\text { (PEDOT): polystyrene sulfonate } \\
\text { (PSS)-dorsal root ganglia (DRG) cells }\end{array}$ & In vitro & $\begin{array}{l}\text { Conductive hydrogel improved } \\
\text { regulation and stimulation of } \\
\text { cell behavior. }\end{array}$ & [80] \\
\hline Microextrusion & Collagen-heparin sulfate- NSCs & In vivo (rat SCI model) & $\begin{array}{l}\text { Improved locomotor function } \\
\text { was observed. }\end{array}$ & [73] \\
\hline Microextrusion & $\begin{array}{l}\text { Gelatin/fibrin and GelMa-neural } \\
\text { progenitor cells (NPCs) }\end{array}$ & In vitro & $\begin{array}{l}\text { Bioprinted NPCs differentiated and } \\
\text { extended axons throughout } \\
\text { microscale scaffold channels. }\end{array}$ & {$[75]$} \\
\hline $\begin{array}{l}\text { Micro-scale continuous } \\
\text { projection printing }(\mu \mathrm{CPP})\end{array}$ & PEGDA-GelMa-NPCs & In vivo (rat SCI model) & $\begin{array}{l}\text { Injured host axons were regenerated } \\
\text { in the scaffolds and formed synapse } \\
\text { onto NPCs implanted into } \\
\text { the scaffold. }\end{array}$ & [81] \\
\hline Microextrusion & $\begin{array}{c}\text { chitosan, hyaluronic acid derivatives, } \\
\text { and Matrigel-NSCs }\end{array}$ & In vivo (rat SCI model) & $\begin{array}{l}\text { Bioprinted scaffolds promoted axon } \\
\text { regeneration and decreased glial scar } \\
\text { deposition, leading to significant } \\
\text { locomotor recovery of SCI model rats. }\end{array}$ & {$[66]$} \\
\hline
\end{tabular}




\section{Conclusions and Future Perspectives}

Neural tissue engineering is an interesting field of science that could facilitate function recovery at the injured site of the nervous system via the use of therapeutic agents. To date, much effort has been made in the field of SCI treatment, and several types of therapeutic methods have been introduced, among which the most interesting are 3D bioprinting scaffolds, which are capable of combining neural grafts with different bioactive factors and cells. The 3D bioprinting technique is a rapidly growing method that could be used in the generation of highly complex scaffolds with the ability of holding stem cells, which are good candidates for the promotion of regeneration of neurons and accelerating the treatment process. Three dimensionally bioprinted scaffolds, which are fabricated via different methods, could overcome the limitations of other methods, such as their high cost, complexity, and risk of immune rejection and activation. On the other hand, they may also have limitations in terms of the types and number of used materials, the resolution of the constructed bioprint, and the maintenance of the viability of stem cells and promotion of their differentiation. Moreover, several aspects must be addressed before a cell type can be distributed as a commercially viable cell source, including safety, efficiency, cost, and the possibility of large-scale manufacturing. Each stem cell type has advantages and disadvantages, and it is still needed to determine which cell type shows the most effective treatment for SCI. Information obtained from stem cell-based treatment studies revealed that the use of stem cells could be a promising alternative for SCI therapy. However, numerous studies are needed to find the optimal bioinks and methods for the combined use of 3D bioprinted scaffolds and stem cells in clinical trials. Moreover, 4D printing, which is a new, effective method of fabricating smart responsive scaffolds that can enhance the dynamic interactions between cells and scaffolds, has also been developed; however, this technique is also in its infancy and warrants further investigation.

Funding: This research received no external funding.

Institutional Review Board Statement: Not applicable.

Informed Consent Statement: Not applicable.

Data Availability Statement: Not applicable.

Acknowledgments: Ebrahim Mostafavi would like to acknowledge the support from the National Institute of Biomedical Imaging and Bioengineering (5T32EB009035).

Conflicts of Interest: The authors declare no conflict of interest.

$\begin{array}{ll}\text { Abbreviations } \\ \text { AAV2 } & \text { Adeno-associated virus } \\ \text { AM } & \text { Additive manufacturing } \\ \text { ASCs } & \text { Activated Schwann cells } \\ \text { bFGF } & \text { Basic fibroblast growth factor } \\ \text { Bcl-2 } & \text { B-cell lymphoma-2 } \\ \text { BDNF } & \text { Brain-derived neurotrophic factor } \\ \text { BBB } & \text { Basso-Beattie-Bresnahan } \\ \text { CCL2 } & \text { Chemokine (C-C motif) ligand 2 } \\ \text { CCL5 } & \text { Chemokine (C-C motif) ligand 5 } \\ \text { CNS } & \text { Central nervous system } \\ \text { CAD } & \text { Computer-aided design } \\ \text { CT } & \text { Computer tomography } \\ \text { DLP } & \text { Digital light processing } \\ \text { DRG } & \text { Dorsal root ganglia } \\ \text { EGF } & \text { Epidermal growth factor } \\ \text { FDM } & \text { Fused deposition modeling } \\ \text { FGF } & \text { Fibroblast growth factor } \\ \text { Gap-43 } & \text { Growth-associated protein 43 }\end{array}$




\begin{tabular}{|c|c|}
\hline GAS5 & Growth arrest-specific 5 \\
\hline GDNF & Glial cell-derived neurotrophic factor \\
\hline GelMA & Gelatin methacryloyl \\
\hline GFAP & Glial fibrillary acidic protein \\
\hline hbNSPCs & Brain-derived NSPCs \\
\hline hESC-NS & Human embryonic stem cell-derived neural stem cells \\
\hline hiPSCs & Human-induced pluripotent stem cells \\
\hline hNSCs & Human neural stem cells \\
\hline HRE & Hypoxia response element \\
\hline hscNSPCs & Spinal cord-derived NSPCs \\
\hline IL-4 & Interleukin 4 \\
\hline IL-13 & Interleukin 13 \\
\hline iPSCs & Induced pluripotent stem cells \\
\hline iPSC-NSCs & iPSC-derived neural stem cells \\
\hline lncRNA-GAS5 & Long non-coding RNA-growth arrest-specific transcript 5 \\
\hline LOM & Laminated object manufacturing \\
\hline MJM & Multi-jet modeling \\
\hline MRI & Magnetic resonance imaging \\
\hline NGC & Nerve guidance conduits \\
\hline NSCs & Neural stem cells \\
\hline NSPCs & Neural stem/progenitor cells \\
\hline NPCs & Neural progenitor cells \\
\hline NT-3 & Neurotrophin-3 \\
\hline OPCs & Oligodendrocyte progenitor cells \\
\hline PACAP & Pituitary adenylate cyclase-activating peptide \\
\hline PCL & Polycaprolactone \\
\hline PEDOT & Poly(3,4-ethylenedioxythiophene) \\
\hline PEGDA-NSCs & Poly(ethylene glycol) diacrylate-neural stem cells \\
\hline PSS & Polystyrene sulfonate \\
\hline RT-PCR & Real-time polymerase chain reaction \\
\hline SCI & Spinal cord injury \\
\hline SEM & Standard error of mean \\
\hline Siglec-9 & Sialic acid-binding Ig-like lectin 9 \\
\hline SLA & Stereolithography \\
\hline sNPCs & Spinal neural progenitor cells \\
\hline SLS & Selective laser sintering \\
\hline TrkB & Tropomyosin receptor kinase B \\
\hline $3 \mathrm{D}$ & Three-dimensional \\
\hline UV & Ultraviolet \\
\hline
\end{tabular}

\section{References}

1. Xie, X.; Chen, Y.; Wang, X.; Xu, X.; Shen, Y.; Khan, A.u.R.; Aldalbahi, A.; Fetz, A.E.; Bowlin, G.L.; El-Newehy, M.; et al. Electrospinning nanofiber scaffolds for soft and hard tissue regeneration. J. Mater. Sci. Technol. 2020, 59, 243-261. [CrossRef]

2. Zou, Y.; Ma, D.; Shen, H.; Zhao, Y.; Xu, B.; Fan, Y.; Sun, Z.; Chen, B.; Xue, W.; Shi, Y. Aligned collagen scaffold combination with human spinal cord-derived neural stem cells to improve spinal cord injury repair. Biomater. Sci. 2020, 8, 5145-5156. [CrossRef] [PubMed]

3. Man, W.; Yang, S.; Cao, Z.; Lu, J.; Kong, X.; Sun, X.; Zhao, L.; Guo, Y.; Yao, S.; Wang, G. A multi-modal delivery strategy for spinal cord regeneration using a composite hydrogel presenting biophysical and biochemical cues synergistically. Biomaterials 2021, 276, 120971. [CrossRef] [PubMed]

4. Rodríguez-Barrera, R.; Rivas-González, M.; García-Sánchez, J.; Mojica-Torres, D.; Ibarra, A. Neurogenesis after Spinal Cord Injury: State of the Art. Cells 2021, 10, 1499. [CrossRef] [PubMed]

5. Maas, A.I.; Peul, W.; Thomé, C. Surgical decompression in acute spinal cord injury: Earlier is better. Lancet Neurol. 2021, 20 , 84-86. [CrossRef]

6. Collis, J. Therapeutic hypothermia in acute traumatic spinal cord injury. BMJ Mil. Health 2018, 164, 214-220. [CrossRef] [PubMed]

7. Islamov, R.; Bashirov, F.; Fadeev, F.; Shevchenko, R.; Izmailov, A.; Markosyan, V.; Sokolov, M.; Kuznetsov, M.; Davleeva, M.; Garifulin, R. Epidural stimulation combined with triple gene therapy for spinal cord injury treatment. Int. J. Mol. Sci. 2020, 21, 8896. [CrossRef] [PubMed] 
8. Bishop, E.S.; Mostafa, S.; Pakvasa, M.; Luu, H.H.; Lee, M.J.; Wolf, J.M.; Ameer, G.A.; He, T.-C.; Reid, R.R. 3-D bioprinting technologies in tissue engineering and regenerative medicine: Current and future trends. Genes Dis. 2017, 4, 185-195. [CrossRef] [PubMed]

9. Ahmad, N.; Gopinath, P.; Dutta, R. 3D printing Technology in Nanomedicine; Elsevier: Amsterdam, The Netherlands, 2019.

10. Yousefifard, M.; Maleki, S.N.; Askarian-Amiri, S.; Vaccaro, A.R.; Chapman, J.R.; Fehlings, M.G.; Hosseini, M.; Rahimi-Movaghar, V. A combination of mesenchymal stem cells and scaffolds promotes motor functional recovery in spinal cord injury: A systematic review and meta-analysis. J. Neurosurg. Spine 2019, 32, 269-284. [CrossRef]

11. Fan, L.; Liu, C.; Chen, X.; Zou, Y.; Zhou, Z.; Lin, C.; Tan, G.; Zhou, L.; Ning, C.; Wang, Q. Directing induced pluripotent stem cell derived neural stem cell fate with a three-dimensional biomimetic hydrogel for spinal cord injury repair. ACS Appl. Mater. Interfaces 2018, 10, 17742-17755. [CrossRef] [PubMed]

12. Ahuja, C.S.; Fehlings, M. Concise review: Bridging the gap: Novel neuroregenerative and neuroprotective strategies in spinal cord injury. Stem Cells Transl. Med. 2016, 5, 914-924. [CrossRef] [PubMed]

13. Ahi, Z.B.; Assunção-Silva, R.C.; Salgado, A.J.; Tuzlakoglu, K. A combinatorial approach for spinal cord injury repair using multifunctional collagen-based matrices: Development, characterization and impact on cell adhesion and axonal growth. Biomed. Mater. 2020, 15, 055024. [CrossRef] [PubMed]

14. Xu, B.; Zhao, Y.; Xiao, Z.; Wang, B.; Liang, H.; Li, X.; Fang, Y.; Han, S.; Li, X.; Fan, C. A dual functional scaffold tethered with EGFR antibody promotes neural stem cell retention and neuronal differentiation for spinal cord injury repair. Adv. Healthc. Mater. 2017, 6, 1601279. [CrossRef]

15. Liu, S.; Xie, Y.-Y.; Wang, L.-D.; Tai, C.-X.; Chen, D.; Mu, D.; Cui, Y.-Y.; Wang, B. A multi-channel collagen scaffold loaded with neural stem cells for the repair of spinal cord injury. Neural Regen. Res. 2021, 16, 2284.

16. Lv, B.; Zhang, X.; Yuan, J.; Chen, Y.; Ding, H.; Cao, X.; Huang, A. Biomaterial-supported MSC transplantation enhances cell-cell communication for spinal cord injury. Stem Cell Res. Ther. 2021, 12, 36. [CrossRef] [PubMed]

17. Guo, S.; Redenski, I.; Levenberg, S. Spinal Cord Repair: From Cells and Tissue Engineering to Extracellular Vesicles. Cells 2021, 10, 1872. [CrossRef] [PubMed]

18. Zakrzewski, W.; Dobrzyński, M.; Szymonowicz, M.; Rybak, Z. Stem cells: Past, present, and future. Stem Cell Res. Ther. 2019, 10, 68. [CrossRef] [PubMed]

19. Huang, L.; Fu, C.; Xiong, F.; He, C.; Wei, Q. Stem Cell Therapy for Spinal Cord Injury. Cell Transplant. 2021, 30, 0963689721989266. [CrossRef] [PubMed]

20. Katoh, H.; Yokota, K.; Fehlings, M.G. Regeneration of spinal cord connectivity through stem cell transplantation and biomaterial scaffolds. Front. Cell. Neurosci. 2019, 13, 248. [CrossRef] [PubMed]

21. Hu, X.-C.; Lu, Y.-B.; Yang, Y.-N.; Kang, X.-W.; Wang, Y.-G.; Ma, B.; Xing, S. Progress in clinical trials of cell transplantation for the treatment of spinal cord injury: How many questions remain unanswered? Neural Regen. Res. 2021, 16, 405. [PubMed]

22. Johnson, L.D.; Pickard, M.R.; Johnson, W.E. The Comparative Effects of Mesenchymal Stem Cell Transplantation Therapy for Spinal Cord Injury in Humans and Animal Models: A Systematic Review and Meta-Analysis. Biology 2021, 10, 230. [CrossRef] [PubMed]

23. Shao, A.; Tu, S.; Lu, J.; Zhang, J. Crosstalk between stem cell and spinal cord injury: Pathophysiology and treatment strategies. Stem Cell Res. Ther. 2019, 10, 238. [CrossRef] [PubMed]

24. Shinozaki, M.; Nagoshi, N.; Nakamura, M.; Okano, H. Mechanisms of Stem Cell Therapy in Spinal Cord Injuries. Cells 2021, 10, 2676. [CrossRef] [PubMed]

25. Gao, L.; Peng, Y.; Xu, W.; He, P.; Li, T.; Lu, X.; Chen, G. Progress in stem cell therapy for spinal cord injury. Stem Cells Int. 2020, 2020, 2853650. [CrossRef]

26. Pandamooz, S.; Salehi, M.S.; Zibaii, M.I.; Ahmadiani, A.; Nabiuni, M.; Dargahi, L. Epidermal neural crest stem cell-derived glia enhance neurotrophic elements in an ex vivo model of spinal cord injury. J. Cell. Biochem. 2018, 119, 3486-3496. [CrossRef] [PubMed]

27. Torrillas De La Cal, A.; Paniagua-Torija, B.; Arevalo-Martin, A.; Faulkes, C.G.; Jiménez, A.J.; Ferrer, I.; Molina-Holgado, E.; Garcia-Ovejero, D. The Structure of the Spinal Cord Ependymal Region in Adult Humans Is a Distinctive Trait among Mammals. Cells 2021, 10, 2235. [CrossRef]

28. Zhang, Y.; Xu, X.; Tong, Y.; Zhou, X.; Du, J.; Choi, I.Y.; Yue, S.; Lee, G.; Johnson, B.N.; Jia, X. Therapeutic effects of peripherally administrated neural crest stem cells on pain and spinal cord changes after sciatic nerve transection. Stem Cell Res. Therapy 2021, 12, 180. [CrossRef]

29. Xue, W.; Fan, C.; Chen, B.; Zhao, Y.; Xiao, Z.; Dai, J. Direct neuronal differentiation of neural stem cells for spinal cord injury repair. STEM CELLS 2021, 39, 1025-1032. [CrossRef]

30. Islamov, R.R.; Izmailov, A.A.; Sokolov, M.E.; Fadeev, P.O.; Bashirov, F.V.; Eremeev, A.A.; Shaymardanova, G.F.; Shmarov, M.M.; Naroditskiy, B.S.; Chelyshev, Y.A.; et al. Evaluation of direct and cell-mediated triple-gene therapy in spinal cord injury in rats. Brain Res. Bull. 2017, 132, 44-52. [CrossRef]

31. Nejati-Koshki, K.; Mortazavi, Y.; Pilehvar-Soltanahmadi, Y.; Sheoran, S.; Zarghami, N. An update on application of nanotechnology and stem cells in spinal cord injury regeneration. Biomed. Pharmacother. 2017, 90, 85-92. [CrossRef] 
32. Zhao, Y.; Tang, F.; Xiao, Z.; Han, G.; Wang, N.; Yin, N.; Chen, B.; Jiang, X.; Yun, C.; Han, W. Clinical study of NeuroRegen scaffold combined with human mesenchymal stem cells for the repair of chronic complete spinal cord injury. Cell Transplant. 2017, 26, 891-900. [CrossRef]

33. Suzuki, H.; Sakai, T. Current Concepts of Stem Cell Therapy for Chronic Spinal Cord Injury. Int. J. Mol. Sci. 2021, 22, 7435. [CrossRef] [PubMed]

34. Veenvliet, J.V.; Bolondi, A.; Kretzmer, H.; Haut, L.; Scholze-Wittler, M.; Schifferl, D.; Koch, F.; Guignard, L.; Kumar, A.S.; Pustet, M. Mouse embryonic stem cells self-organize into trunk-like structures with neural tube and somites. Science 2020, $370,6522$. [CrossRef] [PubMed]

35. Jones, I.; Novikova, L.N.; Wiberg, M.; Carlsson, L.; Novikov, L.N. Human Embryonic Stem Cell-derived Neural Crest Cells Promote Sprouting and Motor Recovery Following Spinal Cord Injury in Adult Rats. Cell Transplant. 2021, 30, 0963689720988245. [CrossRef] [PubMed]

36. Zarei-Kheirabadi, M.; Sadrosadat, H.; Mohammadshirazi, A.; Jaberi, R.; Sorouri, F.; Khayyatan, F.; Kiani, S. Human embryonic stem cell-derived neural stem cells encapsulated in hyaluronic acid promotes regeneration in a contusion spinal cord injured rat. Int. J. Biol. Macromol. 2020, 148, 1118-1129. [CrossRef] [PubMed]

37. Li, Y.; Shen, P.-P.; Wang, B. Induced pluripotent stem cell technology for spinal cord injury: A promising alternative therapy. Neural Regen. Res. 2021, 16, 1500. [PubMed]

38. Moradi, S.; Mahdizadeh, H.; Šarić, T.; Kim, J.; Harati, J.; Shahsavarani, H.; Greber, B.; Moore, J.B. Research and therapy with induced pluripotent stem cells (iPSCs): Social, legal, and ethical considerations. Stem Cell Res. Ther. 2019, 10, 341. [CrossRef]

39. Shao, R.; Li, C.; Chen, Y.; Zhang, L.; Yang, H.; Zhang, Z.; Yue, J.; Gao, W.; Zhu, H.; Pan, H. LncRNA-GAS5 promotes spinal cord repair and the inhibition of neuronal apoptosis via the transplantation of 3D printed scaffold loaded with induced pluripotent stem cell-derived neural stem cells. Ann. Transl. Med. 2021, 9, 931. [CrossRef]

40. Kajikawa, K.; Imaizumi, K.; Shinozaki, M.; Shibata, S.; Shindo, T.; Kitagawa, T.; Shibata, R.; Kamata, Y.; Kojima, K.; Nagoshi, N. Cell therapy for spinal cord injury by using human iPSC-derived region-specific neural progenitor cells. Mol. Brain 2020, 13, 120. [CrossRef] [PubMed]

41. Ocansey, D.K.W.; Pei, B.; Yan, Y.; Qian, H.; Zhang, X.; Xu, W.; Mao, F. Improved therapeutics of modified mesenchymal stem cells: An update. J. Transl. Med. 2020, 18, 42. [CrossRef]

42. An, N.; Yang, J.; Wang, H.; Sun, S.; Wu, H.; Li, L.; Li, M. Mechanism of mesenchymal stem cells in spinal cord injury repair through macrophage polarization. Cell Biosci. 2021, 11, 41. [CrossRef] [PubMed]

43. Sykova, E.; Cizkova, D.; Kubinova, S. Mesenchymal Stem Cells in Treatment of Spinal Cord Injury and Amyotrophic Lateral Sclerosis. Front. Cell Dev. Biol. 2021, 9, 695900. [CrossRef]

44. Pereira, I.M.; Marote, A.; Salgado, A.J.; Silva, N.A. Filling the gap: Neural stem cells as a promising therapy for spinal cord injury. Pharmaceuticals 2019, 12, 65. [CrossRef]

45. Zhu, S.; Ying, Y.; Ye, J.; Chen, M.; Wu, Q.; Dou, H.; Ni, W.; Xu, H.; Xu, J. AAV2-mediated and hypoxia response element-directed expression of bFGF in neural stem cells showed therapeutic effects on spinal cord injury in rats. Cell Death Dis. 2021, 12, 274. [CrossRef]

46. Voronova, A.; Stepanova, O.; Valikhov, M.; Chadin, A.; Semkina, A.; Karsuntseva, E.; Fursa, G.; Reshetov, I.; Chekhonin, V. Combined Preparation of Human Olfactory Ensheathing Cells in the Therapy of Post-Traumatic Cysts of the Spinal Cord. Bull. Exp. Biol. Med. 2020, 169, 539-543. [CrossRef]

47. Gazdic, M.; Volarevic, V.; Harrell, C.R.; Fellabaum, C.; Jovicic, N.; Arsenijevic, N.; Stojkovic, M. Stem cells therapy for spinal cord injury. Int. J. Mol. Sci. 2018, 19, 1039. [CrossRef] [PubMed]

48. Cofano, F.; Boido, M.; Monticelli, M.; Zenga, F.; Ducati, A.; Vercelli, A.; Garbossa, D. Mesenchymal stem cells for spinal cord injury: Current options, limitations, and future of cell therapy. Int. J. Mol. Sci. 2019, 20, 2698. [CrossRef] [PubMed]

49. Ronaghi, M.; Erceg, S.; Moreno-Manzano, V.; Stojkovic, M. Challenges of stem cell therapy for spinal cord injury: Human embryonic stem cells, endogenous neural stem cells, or induced pluripotent stem cells? Stem Cells 2010, 28, 93-99. [CrossRef]

50. Shortiss, C.; Howard, L.; McMahon, S.S. Lentiviral Vectors Delivered with Biomaterials as Therapeutics for Spinal Cord Injury. Cells 2021, 10, 2102. [CrossRef]

51. Zheng, Y.; Mao, Y.-R.; Yuan, T.-F.; Xu, D.-S.; Cheng, L.-M. Multimodal treatment for spinal cord injury: A sword of neuroregeneration upon neuromodulation. Neural Regen. Res. 2020, 15, 1437. [PubMed]

52. Silva, N.A.; Sousa, N.; Reis, R.L.; Salgado, A.J. From basics to clinical: A comprehensive review on spinal cord injury. Prog. Neurobiol. 2014, 114, 25-57. [CrossRef]

53. Zhu, W.; Castro, N.; Zhang, L.G. Nanotechnology and 3D bioprinting for neural tissue regeneration. In 3D Bioprinting and Nanotechnology in Tissue Engineering and Regenerative Medicine, 1st ed.; Academic Press: London, UK, 2015 ; pp. $307-331$.

54. Cheng, T.; Qu, H.; Zhang, G.; Zhang, X. Osteogenic and antibacterial properties of vancomycin-laden mesoporous bioglass/PLGA composite scaffolds for bone regeneration in infected bone defects. Artif. Cells Nanomed. Biotechnol. 2018, 46, 1935-1947. [CrossRef] [PubMed]

55. Liao, S.; Cui, F.; Zhang, W.; Feng, Q. Hierarchically biomimetic bone scaffold materials: Nano-HA/collagen/PLA composite. J. Biomed. Mater. Res. Part B 2004, 69B, 158-165. [CrossRef] [PubMed]

56. Manavitehrani, I.; Le, T.Y.L.; Daly, S.; Wang, Y.; Maitz, P.K.; Schindeler, A.; Dehghani, F. Formation of porous biodegradable scaffolds based on poly(propylene carbonate) using gas foaming technology. Mater. Sci. Eng. C 2019, 96, 824-830. [CrossRef] 
57. Haider, A.; Haider, S.; Rao Kummara, M.; Kamal, T.; Alghyamah, A.-A.A.; Jan Iftikhar, F.; Bano, B.; Khan, N.; Amjid Afridi, M.; Soo Han, S.; et al. Advances in the scaffolds fabrication techniques using biocompatible polymers and their biomedical application: A technical and statistical review. J. Saudi Chem. Soc. 2020, 24, 186-215. [CrossRef]

58. Ameer, J.M.; Pr, A.K.; Kasoju, N. Strategies to tune electrospun scaffold porosity for effective cell response in tissue engineering. J. Funct. Biomater. 2019, 10, 30. [CrossRef]

59. Bose, S.; Koski, C.; Vu, A.A. Additive manufacturing of natural biopolymers and composites for bone tissue engineering. Mater. Horiz. 2020, 7, 2011-2027. [CrossRef]

60. Gu, B.K.; Choi, D.J.; Park, S.J.; Kim, Y.-J.; Kim, C.-H. 3D bioprinting technologies for tissue engineering applications. Cut. Edge Enabling Technol. Regen. Med. 2018, 1078, 15-28.

61. Mishra, D.K.; Pandey, P.M. Experimental investigation into the fabrication of green body developed by micro-extrusion-based 3D printing process. Polym. Compos. 2020, 41, 1986-2002. [CrossRef]

62. Tejo-Otero, A.; Buj-Corral, I.; Fenollosa-Artés, F. 3D printing in medicine for preoperative surgical planning: A review. Ann. Biomed. Eng. 2020, 48, 536-555. [CrossRef] [PubMed]

63. Singh, M.; Haring, A.P.; Tong, Y.; Cesewski, E.; Ball, E.; Jasper, R.; Davis, E.M.; Johnson, B.N. Additive manufacturing of mechanically isotropic thin films and membranes via microextrusion 3D printing of polymer solutions. ACS Appl. Mater. Interfaces 2019, 11, 6652-6661. [CrossRef] [PubMed]

64. Vijayavenkataraman, S.; Fuh, J.Y.; Lu, W.F. 3D printing and 3D bioprinting in pediatrics. Bioengineering 2017, 4, 63. [CrossRef]

65. Vijayavenkataraman, S.; Lu, W.; Fuh, J.Y.H. 3D bioprinting-an ethical, legal and social aspects (ELSA) framework. Bioprinting 2016, 1, 11-21. [CrossRef]

66. Liu, X.; Hao, M.; Chen, Z.; Zhang, T.; Huang, J.; Dai, J.; Zhang, Z. 3D bioprinted neural tissue constructs for spinal cord injury repair. Biomaterials 2021, 272, 120771. [CrossRef]

67. Lin, C.; Ekblad-Nordberg, Å.; Michaëlsson, J.; Götherström, C.; Hsu, C.-C.; Ye, H.; Johansson, J.; Rising, A.; Sundström, E.; Åkesson, E. In Vitro Study of Human Immune Responses to Hyaluronic Acid Hydrogels, Recombinant Spidroins and Human Neural Progenitor Cells of Relevance to Spinal Cord Injury Repair. Cells 2021, 10, 1713. [CrossRef]

68. Gao, G.; Cui, X. Three-dimensional bioprinting in tissue engineering and regenerative medicine. Biotechnol. Lett. 2016, 38, $203-211$. [CrossRef]

69. Hospodiuk, M.; Dey, M.; Sosnoski, D.; Ozbolat, I.T. The bioink: A comprehensive review on bioprintable materials. Biotechnol. Adv. 2017, 35, 217-239. [CrossRef]

70. De la Vega, L.; Rosas Gómez, D.A.; Abelseth, E.; Abelseth, L.; Allisson da Silva, V.; Willerth, S.M. 3D bioprinting human induced pluripotent stem cell-derived neural tissues using a novel lab-on-a-printer technology. Appl. Sci. 2018, 8, 2414. [CrossRef]

71. Zhou, X.; Shi, G.; Fan, B.; Cheng, X.; Zhang, X.; Wang, X.; Liu, S.; Hao, Y.; Wei, Z.; Wang, L. Polycaprolactone electrospun fiber scaffold loaded with iPSCs-NSCs and ASCs as a novel tissue engineering scaffold for the treatment of spinal cord injury. Int. J. Nanomed. 2018, 13, 6265. [CrossRef]

72. Yu, X.; Zhang, T.; Li, Y. 3D Printing and Bioprinting Nerve Conduits for Neural Tissue Engineering. Polymers 2020, $12,1637$. [CrossRef]

73. Chen, C.; Zhao, M.L.; Zhang, R.K.; Lu, G.; Zhao, C.Y.; Fu, F.; Sun, H.T.; Zhang, S.; Tu, Y.; Li, X.H. Collagen/heparin sulfate scaffolds fabricated by a 3D bioprinter improved mechanical properties and neurological function after spinal cord injury in rats J. Biomed. Mater. Res. Part A 2017, 105, 1324-1332. [CrossRef] [PubMed]

74. Jiang, J.-P.; Liu, X.-Y.; Zhao, F.; Zhu, X.; Li, X.-Y.; Niu, X.-G.; Yao, Z.-T.; Dai, C.; Xu, H.-Y.; Ma, K. Three-dimensional bioprinting collagen/silk fibroin scaffold combined with neural stem cells promotes nerve regeneration after spinal cord injury. Neural Regen. Res. 2020, 15, 959.

75. Joung, D.; Truong, V.; Neitzke, C.C.; Guo, S.Z.; Walsh, P.J.; Monat, J.R.; Meng, F.; Park, S.H.; Dutton, J.R.; Parr, A.M. 3D printed stem-cell derived neural progenitors generate spinal cord scaffolds. Adv. Funct. Mater. 2018, 28, 1801850. [CrossRef]

76. Hsieh, F.-Y.; Lin, H.-H.; Hsu, S.-h. 3D bioprinting of neural stem cell-laden thermoresponsive biodegradable polyurethane hydrogel and potential in central nervous system repair. Biomaterials 2015, 71, 48-57. [CrossRef]

77. Gu, Q.; Tomaskovic-Crook, E.; Lozano, R.; Chen, Y.; Kapsa, R.M.; Zhou, Q.; Wallace, G.G.; Crook, J.M. Functional 3D neural mini-tissues from printed gel-based bioink and human neural stem cells. Adv. Healthc. Mater. 2016, 5, 1429-1438. [CrossRef]

78. Zhu, W.; Harris, B.T.; Zhang, L.G. Gelatin methacrylamide hydrogel with graphene nanoplatelets for neural cell-laden 3D bioprinting. In Proceedings of the 2016 38th Annual International Conference of the IEEE Engineering in Medicine and Biology Society (EMBC), Orlando, FL, USA, 16-20 August 2016; pp. 4185-4188.

79. Zhu, W.; George, J.K.; Sorger, V.J.; Zhang, L.G. 3D printing scaffold coupled with low level light therapy for neural tissue regeneration. Biofabrication 2017, 9, 025002. [CrossRef]

80. Heo, D.N.; Lee, S.-J.; Timsina, R.; Qiu, X.; Castro, N.J.; Zhang, L.G. Development of 3D printable conductive hydrogel with crystallized PEDOT: PSS for neural tissue engineering. Mater. Sci. Eng. C 2019, 99, 582-590. [CrossRef]

81. Koffler, J.; Zhu, W.; Qu, X.; Platoshyn, O.; Dulin, J.N.; Brock, J.; Graham, L.; Lu, P.; Sakamoto, J.; Marsala, M. Biomimetic 3D-printed scaffolds for spinal cord injury repair. Nat. Med. 2019, 25, 263-269. [CrossRef] [PubMed] 